LA.UR $84-24,23$

LA-UR--84-2423

DE85 008626

SALT-GRADIENT SOLAR PONDS

authonis) Donald A. Neeper
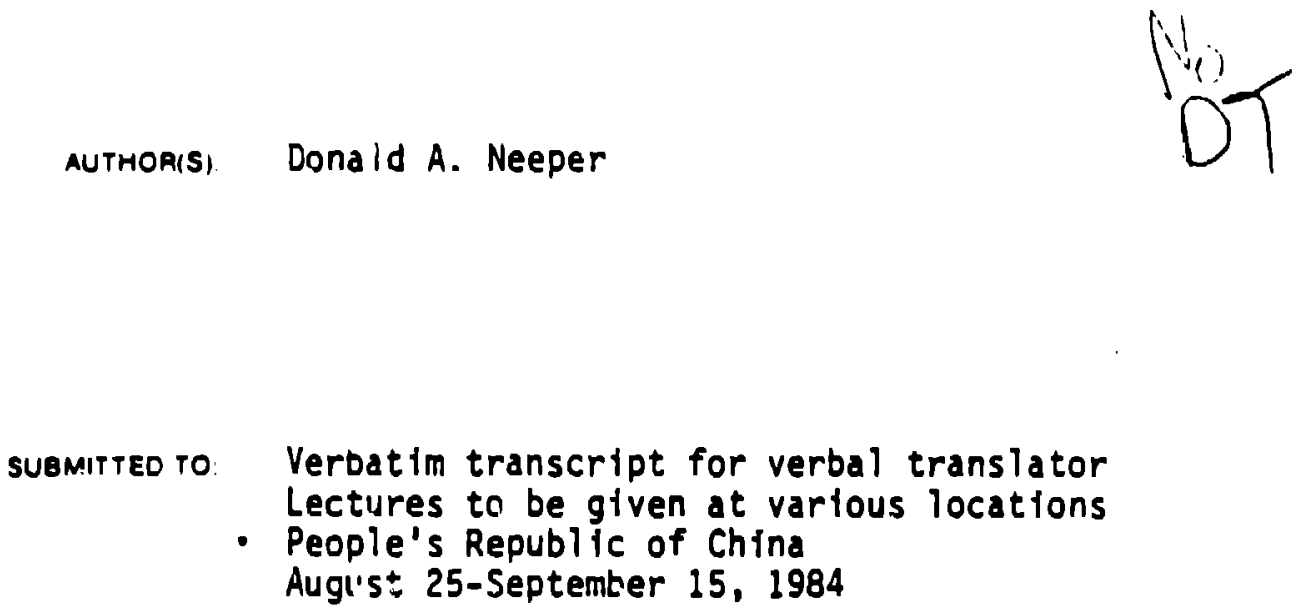

\title{
DISC 'IAIMER
}

This report was prepured as all account of work spousored by an anency of the : Inited Stutes Governmen'. Neither the l/rited Silutes (iovernment bor uny agency thereof, nor any of their cmployecs, makes any will... ty. capress or implicd, or ussumes any legul liability or responsibility for the uccuracy. completeness, or usefulness of uny informution, upparatus, prexluet, or process disclosed, or represent: that its use would not infrings privhtely owned riglits. Refer ence herein (1) uny specific commercinl product, process, or service by trade nume, Irudemurk. manufaclurer, or otherwise dises not necessurily conslifute or imply its endorsement, reconmendation, or fuvoriong by the Inited Situles (iovernment or any unency thereof. 'The views and opinions of authers expressed herein do not necessurily siule or reflect those of the llnited Silles (iuvermment of uny ukency thereot. 


\section{GALT-GADIEUt selar pouns}

Donald A. Meeper

$$
\text { as } \mathrm{J} 578
$$

Los Alanes Hational Laboratory

Los Mlanes, Hev Mexice 97545 USA

\section{Introsuction}

Salt-gradient solar peads are large-area devices for collection and storage of selar energy at teaperatures up to 90 C. Ponds ary be useful because of their lou cost and becase of the lorge anount of theraol energy storage that they provice.

A salt-gradient pond is usually tue to three neters deep. Solt (ussally WaCl) is dissolved in the poed is such a way that the salieity varjes frea 202 at the botion to vearly ol at the top. Injs causes the dessity to increase uth depth, so that convection is preveated uhen the uater at the betton is warner than water at the top. Sunlight pesetrating the pond uaras the uater of the botten of the poad, and the mecenvecting water abeve octs as 3 transparet insulater to retaig the heat. Apprexinately 400 is of salt ore required for each square neter of pond area.

The pad tas three layers (figure 1). The botton layer is about I aeter deep. Deasity and teaperature are constant througheyt this layer because it is convectite. Ihe

ceavection is indicated by circular arreus on the duagran. Ihis layer serves as the theral storage of the pond. The niddla layer dees oot convect. It is strotified, and is about one aeter thich. In this layer, the saliaity and teaperature with decrease upuard. This is called the -gradiect layer of ine pend because both the salinity and the teaperature fora continuous gradierts. The top layer of the pand is convective, and is oilen about 0.4 neters thich. I. the top layer the temperature is clese to the tenperalure of the al:, aab the salinity is hept as jou as possible. The variation of alinity and tenperature vith depth are shous in Figure 2.

Salt continweusly diffuses upuard through the gradient. If the gradient vere to end at an inpenetrable boundary

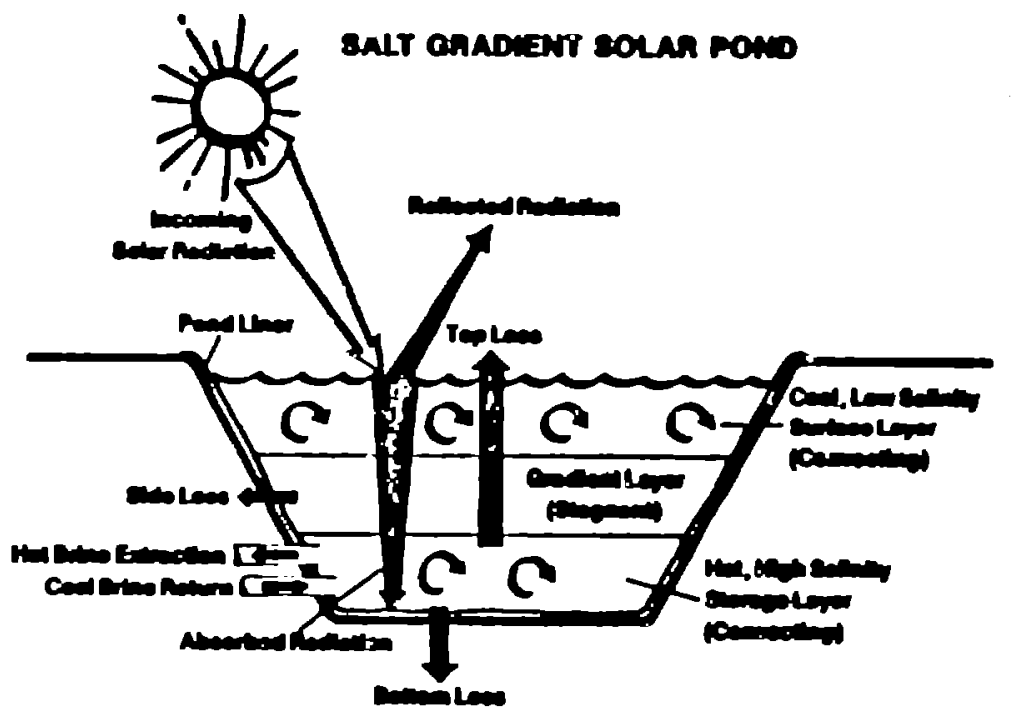

Fig. 1. Diagran of a solar pond.

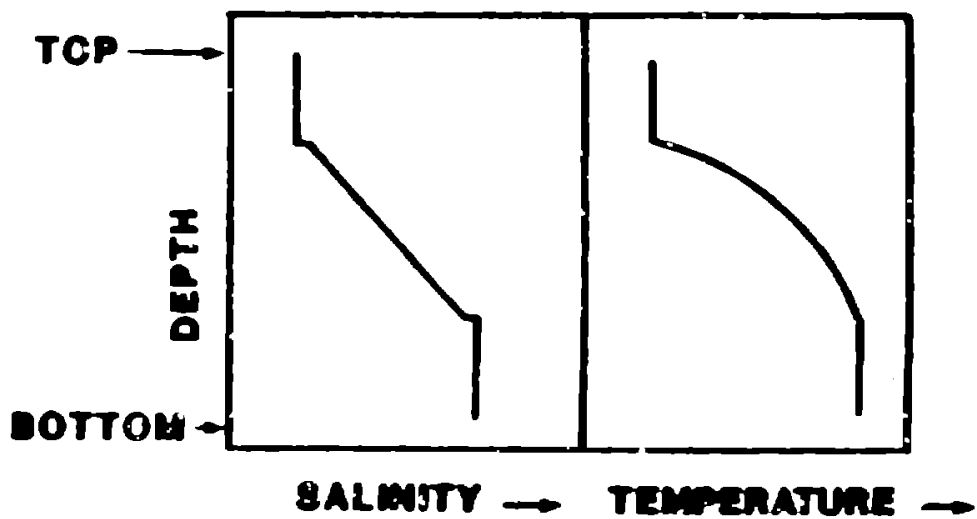

Fig. 2. Hariation of silinity and temerature with depth. 
(such as the air-uater interface), salt could not diffuse

through tar beendari, and salt weuid accunclate of the

boundary. Thus, we see that a salt gradient cannot end at either the betton or the top of the pcad. Therefere,

convecting layers nust exist at lie top and botton of the pend to bring solt to the ond of the gradient at ite botton and to carry salt auay at the top. Ihe boltcn convective layer is useful because it provides the theraal storage. However, the top convective layer serves no useful purpose. Aay solar esergy absorbed in this layer is sinply lost to the alt. Therefore, we wish to kep this layer as this as possible. In practice, the upuard transpert of salt and the airing due to biad aake it difficult to mointain this layer less thas 0.3 neters thick.

Diffusien threugh the gradient, which is about 1 neter thick. causts as upuard salt traspert of about $10 \mathrm{~kg}$ per square neter per year. As l shall explain later, other processes cas canse the total epuard trassport of salt to be as large as 35 kg per square neter per year. The accuatlation of salt 3 the top layer nust be renoved by flusbing with fresh water of vitb uater of lou salinity. such as sed water. Salt must be added to the botton layer of the poud absut once per year.

Ihe infrared pertion is abeut ene-thied of the total incidect selar enargy. This portien is absorbed in the first fer ailliacters of the pend and the energy is lost to the air. Approxiactely one-third of the sualight is absorbed is the gradient layer, and serves to nainiais the temperature gradieat in that loyer. About one-third of the iecident energy reaches the botton gf the pond. The tbeoretical efficiency of the poed is about 20I. In practice, 10I-10z of the iecident selar energy nay becene usefis thernal eaergy. Energy is usually renoved fron the pond by puaping hot salt water fren the bolton layer through a heat exchanger located sear the posd. Houever, a heat exchanger could be placed it the pond cear the tep of the lover couvective layer. 
COASTRUETIOI AHD DAINIEMANCE Of JWE POH

Solar pends are usuolly costructed uith slepdas side walls because it is dificult to construct vertical walls. Decauce lbere can be no diffusion of salt inte vall, the sall gradicat mar a wall nust be parajlel to the wall. If a vall is cal vertical, a line of constad salinity vill ool be herizental near the vall (figure 3 ). Ihis effect vill cause convection cells te eccur eear the uall, with an added upward less of salt and heat. These added loses are propertional to the jength of the perineler of the pond uhile elber galas oed losses are preportional te the area of the aoed. These ceovective losses due to sloping walle have eot been neasured, but they ore bejieved to be lasige.ficaet rar posds lerger thas a feu thousas square meters.

All ponds buill to the U.S. have used a plastic or ruser ceabrace to provert the loss of veter and solt inta the soil. Uorkers is bath the 0,5 . ad I irael hare otetied the we of wateraj cley fer the bettea of the pend, but

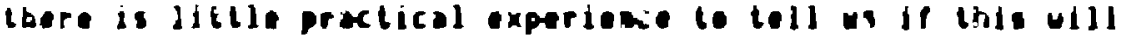
be duccessiul.

The gradient can be eastly formed if the posd is first filled to the level of the aid point of the grodicat with concentratse salt selution. As lalet diffuser (figurs 1 ) is lbed lowerad dobe the pon to the pesition where the scp of the lawer couvectiog layer ulll be. Frest uoler is injected chreugh the diffuser unile it is pulled upuers of tuice the rate thot the top surface of the uoler plits. The fresh

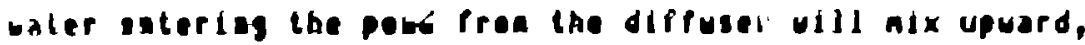
ade tall gradient will be paraed that upproachea zere saliesty at the paist uhare the diffuser reacaes the tep surface of the vater.

Crganic groutb cae be priyented by disselviat a saall anoust of copper silfale in the soll water befere the gradiest is poraed, and by pariodically isjectiag kydrecbleric acid inte the peed is as lo hoep the poed slightly acidic. Wost windbloun dirt will sellle to the bollon of the pood. Leaves froa trees and large pieces of debris should be kept out of the poed because they wil seltle to sone depth in the gradient and pessibly color the uater. The poed should be sufficteatly clear that you can see the print on a neuspaper lyiag on the botton.

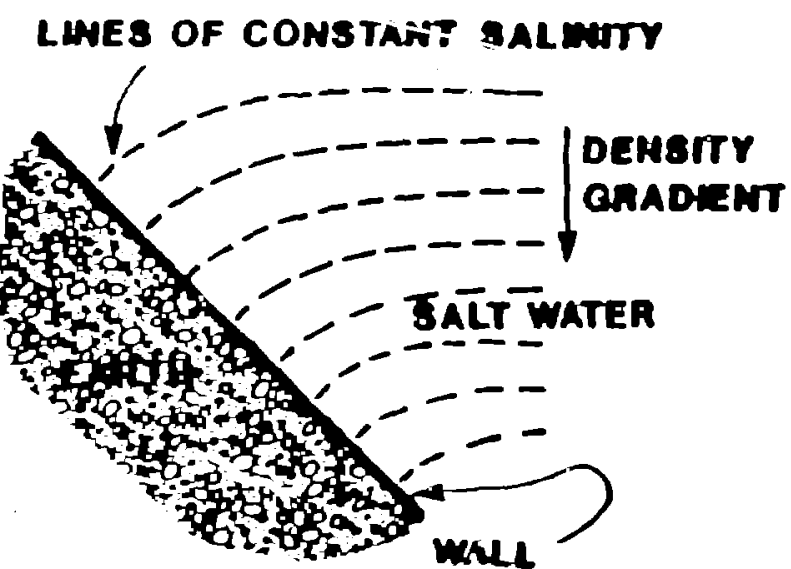

Fig. 3. Lines of constant saifntij near an Imperneable sloptng wajl.

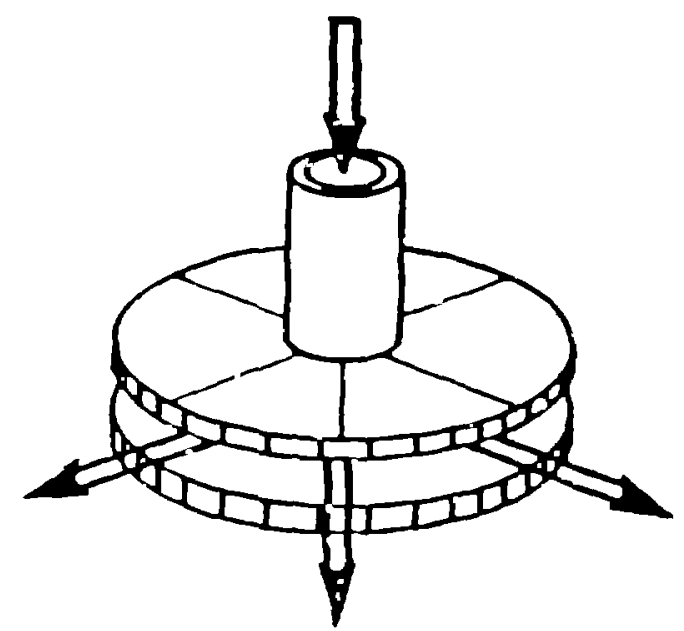

Fig. 4. Diffuser to spread incoming flow hortzontally. 


\section{Mighation of Larers}

A salt grodient of $20 x$ (by weight) salt per neter will not convect with a temperature gradient of $100 \mathrm{C}$ per meter, and will not be greatly harned even by divers going to the botton. Thus, convective stability of the gradient con be assured. Hovever, at high teagerature gradients, the boundarles betueen the layers algrate in such a way as to erode the gradient loyer fren obove and tron balow, thus enlargias the sonvectiog layers. If the tenperature gradient is sufficiently suall, the boundaries of the gradient layer aay nove outuard, enlarging the grodient layer. Figure 5 shous data fron a pond that was oparated with a weak salt gradient, which caused rapid boundary nigration. The dots on the graph shou the measured positions of the beundaries of the gradient layer.

At our laboratery, we hove studied layer nigration with a conputer model, with experinents in laboratory taaks, and with an outdoer pend. We find tha, the heat flux across a boundary is deterained by the teaperature gradient aear the beundary. The sal: flux across the boundary appears to be a unique function of the heat Plux. If the salt flux across the boundary is greater than that which can be renoved or supplied by the salt gradient, aixing will occur at the boundary. The rate of aixing, and cunsequent dastruction of the gradient layer, is reduced if the salt gradient is as large as possible. In figure 5 the solid lises stow the predictions of our computer model, which included entraianent of turbulence due to uind. Although the wind had a significant effect on the top layer, the donianat cause of the layer aigration was eue to the relotionship of salt and heat pluxes at the boundaries.

Carl Mielsen of Ohio state University is attenpting to coatrol boundary aigration by ixjecting snall anounts of concentrated solution just belon the upper toundary of the gradient layer uhde injections smadi anounts of dilute selution just above the lower beundary, thus changing the gradient near the boundary to aatch the solt trassport across the boundary. Other workers repair the gradient layer when necessary by ingection cf brine fron the lower convective layer or dilute solution fron the top layer while noving the diffuser up or dows. Fither nethed of gradient contrel transports salt and heat toward the top of the pond.

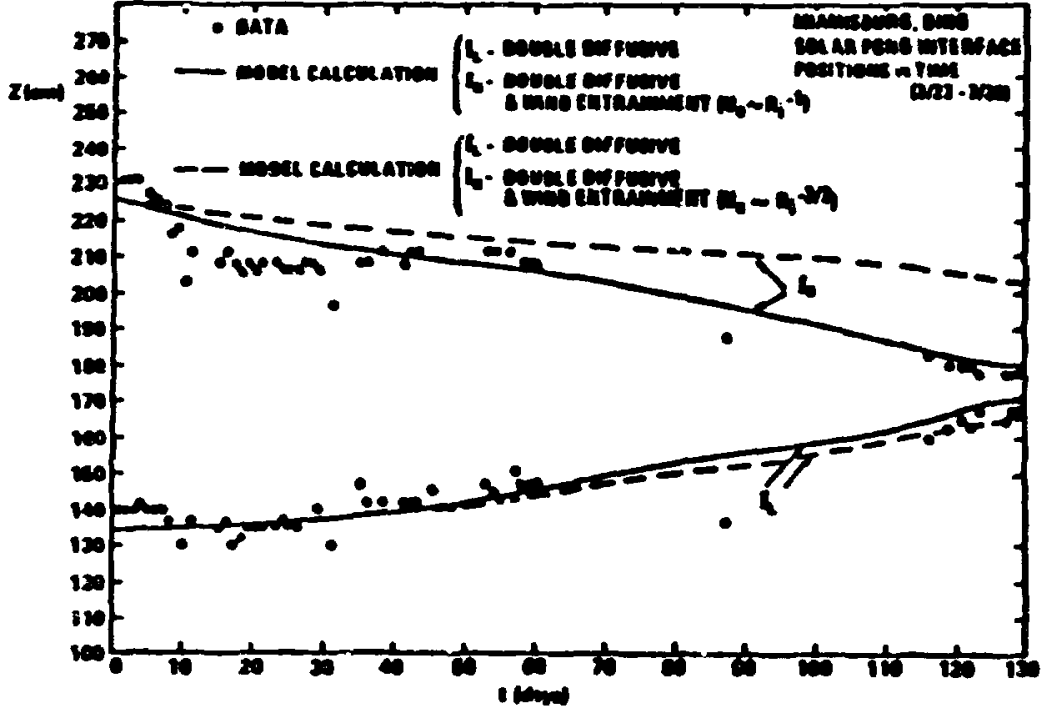

Fig. 5. Position of the measured and calculated positions of the upper and lower boundaries of the convective layer. 
SIATus of solar pamos

Selar posds uth area of 150000 square neters ore beine tested in Israel for prosuction of electric poier. In the U.S., research has been done uith the anteat of using large poeds for electric power and snaller ponds for industrial process heat or heatang and cooling of large buildings. However, 1n the U.S. mD fonds larger than 2000 square neters gave brea tested. I now believe that ponds will te nest ecorgnical in lucotions mear salt lakes or the oceza, where salt has very little cost and where the discharge Pron flushing the top surface of the poad can safely be released wathout danger to the environnent. Any pond will require nonitoring of the gradient and mannienance to keep the gradieat in place. A large poed nay require no nore effort for naintenance than a snall pond. Cunstruction costs, loss of heat through the sides, and convective losses due to the walls all becone snaller, per unit area of the pond, as the posd becones large. Thus, I feel that ponds snaller than several thousand squzre netzers will not be useful. Decause the lasses of energy in conyersion to electricity are so large, the net solar efficiency for conversion to electricity is about 1x. At a latituda of 30 degrees, four negawatls of electric pover can be citained per square killoneler of pond area. This can be econonical if a maturally salty lake can be converted to a solar pond. Ualike other solar devices, a pond can deliver its energy at aight, and a pond 15 not greatly affected by several days of cloudy weather. Thas is because a pond has a very sarje anount of thernal storage. I an therefore hopeful that ponds will be us ad, but I expect that they uill be linited to large apfilisations in mateirally salty locations. At one tine I had hoped that snall ponds (2000-5000 square meters) could be used for healing buildiggs or for proyiding hot water, bu: I wou believe that the nanotenance required by liyer nigration nay nake snall poods toc costly to nperate unless we develop sinple nethods for controlling the gradient.

Horkers in Israel have had sune success with large ponds, but their work has not been published. I nust regard any solar pond as a researsh project, and 1 caution you not to construct a pand uith the tatent of obtaining useful heat before you do experinents, 
I will show sene ghatographs of ponds.

Figlire 6 shous construction of a 2,000 square neter pond for heating a suinning pool. Figure 7 shows the finished pond. This pond has successfully heated a suinning pool, but the pond operators had several bad experiences with leaks and nixinj of layers.

Figure 8 shows a snall researsh pond to which a grain dryer was connected as a denonstration. This pond dio not allain tenperatures above $60 \mathrm{C}$ because leaves fron trees blev into the poad and stained the water.

Figure 9 shows a snall research pond in a sunny clinate with very dry soil. As an experinent, this pana vas allowed to boil. The boiling of the lower convective layer stirred dirt fran the bottion up into the water, and caused some naxing of :ayers, but did not otherwise harn the pono.

Figure 10 shous details of the sandbags and treach used to anchor the rutber nenbrane liner of the pond at our latoratory. Our pani was built by digging vertical side walls into soft volcanic rock. For research purposes, we wanted a snall pond with vertical side walls so that it would sinulate the operation of a large pond by avoiding the cunvection at sloping side walls. Figure 11 shous the side walls after foan insulaticn was applied. For research purposes, we wanted insulated side walls, so that the nixing of layers would not be influenced by loss of heat through the walls. Ithe vertical side valls caused sone stress in the nentrane liner that eventually caused it to tear and leak. Figure 12 shows the installation of tine nenbrane liner. The botton of the pond under the liner was covered with sand to provide a snooth surface for the liner. Figure 13 stious the conpleted pond before salt and water were a.d.je.j. It is 15 neters square and 1 neters deep. Figure 14 sliuws the dunping of salt into the pond, and the linsirunentation rack. Sone rain water is in the botton of the pond. Figu.e 15 shows the conpleted pond. The gradient was formed in one day and the botton layer innediately began warning at the rate of $1 \mathrm{C}$ per day. 
Figure 16 shous a 7000 square neter pond at Ein Dokek, Israel. Experineatal nushes are floating on top of the pond to prevent uind-driven waves. Uorkers in Israei have yenonstrated generation of several hundred kilowatts of electricity fron other ponds.

AFPEMBIX: FLUX RELAIIOUSHIPS

We pind that the relationship between heat flux and salt flux at a boundary can be expressed as:

$$
\frac{\rho C_{C} B F_{S}}{a F_{H}}=0.1455 F_{H}^{-0.13},
$$

19 wich the left side of the equation is dineasionless but fH on the right side is in W/cm2. Bata fron other wurkers :adeate values for the dinensionless ratio as lou as ope-third of our value. This relationstip implies, for exanple, that with a tenperature of $60 \mathrm{C}$ and a teaperature gradiest of $0.5 \mathrm{C} / \mathrm{cm}$, the salinety gradient nust be $6.9 \times 10^{-3}$ $g /$ cot $(0.54 x / i n)$. For a saaller sallaity gradient, the gradieat layer will slouly shriak as the boundary neves into 1t. Ihe rate of eacroachneat depends on the gradients, but is al nost a teu nu per day.

$\rho=$ fluid density $\left(\mathrm{g} / \mathrm{con}^{3}\right)$

$C_{f}=$ heat capacity $\left(\mathrm{J} / \mathrm{g}^{\circ} \mathrm{C}\right)$

$B \quad \cdot \frac{1}{\rho}\left(\frac{\partial \rho}{\partial S}\right)_{T}=$ salinity expansion coefficient

$F_{s}=s a l t$ flux $\left(g / \mathrm{cm}^{2} s\right)$

$F_{H}=$ heat flux $\left(H / \mathrm{cm}^{2}\right)$

$\alpha=-\frac{1}{\rho}\left(\frac{\partial \rho}{\partial T}\right)_{s}=$ coefficient of themal expansion $\left(C^{-1}\right)$ 